\title{
Pengaruh Lama Ekstraksi Kulit Melinjo Merah (Gnetum gnemon L.) Berbantu Gelombang Ultrasonik Terhadap Yield, Fenolik, Flavonoid, Tanin dan Aktivitas Antioksidan
}

\author{
Lisan Mella Rujiyanti ${ }^{\bowtie}$, Bambang Kunarto $^{2}$, Ery Pratiwi ${ }^{3}$ \\ Jurusan Teknologi Hasil Pertanian, Fakultas Teknologi Pertanian, Universitas Semarang, \\ Indonesia
}

DOI: http://dx.doi.org/10.26623/jtphp.v13i1.1845

\section{Info Artikel}

\section{Sejarah Artikel:}

Disubmit 23 April 2020

Direvisi 27 April 2020

Disetujui 5 Mei 2020

\section{Keywords:}

Antioxidant Activity; Melinjo

Red Peels; Ultrasonic; Time

\begin{abstract}
Abstrak
Penelitian ini bertujuan untuk mengetahui yield, fenolik, flavonoid, tanin dan aktivitas antioksidan pada ekstrak kulit melinjo merah dengan berbagai lama ekstraksi berbantu gelombang ultrasonik. Hasil penelitian ini diharapkan dapat memberikan informasi ilmiah kepada masyarakat tentang pemanfaatan ekstraksi kulit melinjo merah berbantu gelombang ultrasonik. Rancangan percobaan yang digunakan adalah Rancangan Acak Kelompok (RAK) dengan 6 perlakuan dan diulang sebanyak 3 kali, yaitu perlakuan lama ekstraksi 10 menit (P1), perlakuan lama ekstraksi 20 menit (P2), perlakuan lama ekstraksi 30 menit (P3), perlakuan lama ekstraksi 40 menit (P4), perlakuan lama ekstraksi 50 menit (P5), dan perlakuan lama ekstraksi 60 menit (P6). Data yang diperoleh dianalisis dengan menggunakan ANOVA, dan apabila perbedaan akibat perlakuan dilanjutkan dengan uji wilayah ganda Duncan (DMRT) pada taraf 0,05\%. Hasil penelitian menunjukkan ekstraksi kulit melinjo merah berbantu gelombang ultrasonik berpengaruh terhadap yield, fenolik, flavonoid, tanin dan aktivitas antioksidan. Untuk mendapatkan yield, fenolik, flavonoid, tanin dan aktivitas antioksidan terbaik adalah pada waktu 30 menit (P3) yang mneghasilkan yield sebesar 17,86\%, fenolik 2,74 mg GAE/g, flavonoid 2,30 mg $\mathrm{QE} / \mathrm{g}$, tanin 2,92 mg TAE/g, dan aktivitas antioksidan sebesar 74,33\%.
\end{abstract}

\section{Abstract}

This research aims to know yield, phenolic, flavonoids, tannins and antioxidant activity on extraction melinjo red peels of extraction times using ultrasonic-assisted extraction. The results of this research are expected to be able to provide scientific information about the utilization of extraction melinjo red peels using ultrasonic-assisted extraction. The experimental design used a randomized block design using 6 treatment and 3 times repeats, which was treatment extraction time 10 minutes $(P 1)$, treatment extraction time 20 minutes (P2), treatment extraction time 30 minutes (P3), treatment extraction time 40 minutes (P4), treatment extraction time 50 minutes (P5), and treatment extraction time 60 minutes (P6). The data obtained were analyzed using ANOVA, and if there is a difference due to the treatment continued with the test area double Duncan (DMRT) at level 0,05\%. Research results showed the extraction of melinjo red peels using ultrasonic-assisted extraction effect on yield, phenolic, flavonoids, tannins and antioxidant activity. To get the yield, phenolic, flavonoids, tannins and antioxidant activity is best with a time 30 minutes (P3), extraction produced a yield 17,86\%, phenolic 2,74 mg GAE/g, flavonoids $2,30 \mathrm{mg} \mathrm{QE} / \mathrm{g}$, tannins 2,92 $\mathrm{mg} \mathrm{TAE} / \mathrm{g}$, and antioxidant activty $74,33 \%$.

\footnotetext{
Alamat Korespondensi: Lisan Mella Rujiyanti, Teknologi Hasil p-ISSN 1693-9115 Pertanian, Universitas Semarang. E-mail: lisanmella3@gmail.com e-ISSN 2580-846X
} 


\section{PENDAHULUAN}

Tanaman melinjo (Gnetum gnemon L.) termasuk famili Gnetaceae yang terdiri dari sekitar 30 spesies (Wazir et al., 2011: Hou et al., 2015). Menurut Badan Pusat Statistik Pertanian Hortikultura pada tahun 2018 terdapat 1.164.665 tanaman melinjo yang menghasilkan buah melinjo sebanyak 512.135 kwintal. Menurut Kunarto dan Pratiwi (2014) untuk tanaman melinjo yang sudah dewasa mampu menghasilkan antara $15.000-20.000$ biji per pohonnya, yang merupakan sebagai bahan baku untuk pembuatan tepung, emping, kripik ataupun produk pangan lainnya. Sedangkan untuk kulit melinjo yag berwarna merah yang berjumlah sekitar 8 ton per hektar belum banyak digunakan.

Kulit melinjo merah mempunyai potensi sebagai antioksidan alami dan dapat menggantikan antioksidan sintetis (BHA, BHT, TBHQ, dan PG). Menurut Kunarto (2014) kulit melinjo yang diekstrak dengan metode maserasi menggunakan etanol 70\% menghasilkan aktivitas antioksidan sebesar 61,0875\% dan Dewi (2018) kulit melinjo yang diekstrak dengan metode maserasi menggunakan etanol $70 \%$ juga menghasilkan aktivitas antioksidan dengan nilai $\mathrm{IC}_{50}$ sebesar 16,73 mg.

Akan tetapi, untuk menghasilkan antioksidan perlu dilakukan ekstraksi. Pemilihan metode ekstraksi sangat penting dilakukan karena hasil ekstraksi akan mencerminkan tingkat keberhasilan metode tersebut. Pada saat ini dikembangkan teknik baru untuk ekstraksi padat-cair suatu produk yaitu dengan menggunakan bantuan gelombang ultrasonik (UAE). Menurut Nipornram et al. (2017) ultrasonic-assisted extraction menunjukkan efisiensi ekstraksi yang lebih tinggi dari metode microwave. Menurut Wen et al. (2018) ekstraksi berbantu gelombang ultrasonik memerlukan waktu yang lebih singkat dan menghasilkan yield produk yang lebih banyak. Kelebihan metode ekstraksi ultrasonik menurut Turrini et al. (2018) yaitu dapat mengurangi volume pelarut, mempercepat proses ekstraksi dan membutuhkan energi yang rendah dibandingkan dengan ekstraksi konvensional.

Ekstraksi berbantu gelombang ultrasonik dipengaruhi oleh beberapa hal, salah satunya lama waktu. Waktu ekstraksi yang terlalu lama serta melampaui batas optimum dapat menyebabkan hilangnya senyawa-senyawa pada larutan karena terjadi proses oksidasi, sedangkan jika waktu ekstraksi yang terlalu singkat akan menyebabkan komponen bioaktif yang terekstrak dari bahan tidak maksimal sehingga komponen bioaktif yang diperoleh akan rendah (Sekarsari et al., 2019). Namun, sampai saat ini belum ada penelitian tentang lama waktu yang terbaik untuk ekstraksi kulit melinjo merah berbantu gelombang ultrasonik.

\section{METODOLOGI PENELITIAN}

\section{Bahan dan Alat}

Bahan yang digunakan yaitu kulit melinjo merah dengan umur \pm 75 hari setelah berbunga yang berasal dari Dukuh Lajer, Desa Bonagung, Kecamatan Penawangan, Kabupaten Grobogan, Purwodadi, Jawa Tengah. Etanol 70\% (Merck, Indonesia), kertas Whatman No. 1, alumunium foil, $\mathrm{AlCl}_{3}, \mathrm{CH}_{3} \mathrm{COOH}$, aquades (Merck, Indonesia), metanol, larutan DPPH, reagen folin ciocalteau, natrium karbonat 7,5\%, dietil eter, $\mathrm{Na}_{2} \mathrm{CO}_{3}$, asam tanat dan quecertin.

Alat yang digunakan dalam pembuatan serbuk kulit melinjo merah meliputi Food dehydrator (Maksindo, Indonesia), ayakan 30 mesh (ASTM Standart, Indonesia), neraca analitik (Ohaus, USA), alat ekstraksi ultrasonik bath (Bronson 3800, Mexico), rotary vacuum evaporator (IKA RV-10, Germany), botol sampel, corong kaca (Pyrex, Indonesia), beaker glass (Pyrex, Indonesia), erlenmeyer (Iwaki Pyrex, Japan), gelas ukur (RRC, China), spatula, pipet volume (Pyrex, Germany), oven listrik (Memmert UN 110), botol kaca (Pyrex), bola hisap (Indonesia), labu ukur (RRC, China), botol timbang, desikator (Indonesia) dan blender. 
PROSEDUR PENELITIAN

Pembuatan Serbuk Kulit Melinjo Merah

Penelitian menggunakan kulit melinjo merah yang telah diperoleh dari pohonnya dengan umur \pm 75 hari setelah berbunga, selanjutnya disortasi untuk memisahkan antara kulit melinjo buruk dan baik. Hasil kulit melinjo merah yang baik dibersihkan, setelah itu dikecilkan ukurannya dengan pisau stainless steel, lalu kulit melinjo merah dikeringkan dengan suhu $50^{\circ} \mathrm{C}$ selama 3,5 jam hingga mencapai kadar air $<10 \%$ menggunakan Food dehydrator. Kulit melinjo merah yang telah kering dihaluskan menggunakan blender selama 2 menit, kemudian disaring dengan ayakan 30 mesh sampai mendapatkan serbuk kulit melinjo merah lolos ayak (Modifikasi dari Kunarto et al., 2019).

\section{Ekstraksi Kulit Melinjo Merah}

Serbuk kulit melinjo merah lolos ayak yang telah didapatkan, dilakukan ekstraksi dengan UAE Bronson 3800 pada suhu $30^{\circ} \mathrm{C}$ selama 10, 20, 30, 40, 50 dan 60 menit dengan bahan : pelarut (1:10). Setelah itu dilakukan penyaringan dengan menggunakan kertas saring Whatman No. 1 untuk menghasilkan ekstrak kulit melinjo merah cair. Kemudian dievaporasi selama 4,5 jam dengan suhu $50^{\circ} \mathrm{C}$ agar mendapatkan ekstrak kulit melinjo merah kental yang selanjutnya dilakukan analisis yield, fenolik, flavonoid, tanin, dan antioksidan (Modifikasi dari Kunarto et al., 2019).

\section{PROSEDUR ANALISIS}

Yield (A1-Juhaimi et al., 2016)

Presentase yield ekstrak dihitung sesuai rumus untuk mendapatkan yield ekstrak dengan formula yaitu berat ekstrak kental dibagi dengan berat sampel kering kemudian dikali dengan 100 .

Fenolik (Margaretta et al., 2011)

Pengujian total fenol dapat dilakukan dengan menggunakan teori FolinCiocalteau. Langkah pertama yang dilakukan adalam menyiapkan sampel sebanyak $2 \mathrm{mg}$ yang kemudian dilarutkan kedalam $1 \mathrm{~mL}$ metanol. Larutan dicampur dengan $5 \mathrm{~mL}$ reagen Folin-ciocalteau 1:10 (w/v) dengan pelarut akuades. Kemudian ditambahkan $4 \mathrm{~mL}$ larutan natrium karbonat 7,5\% (w/v) dengan pelarut akuades. Dibiarkan selama 30 menit pada suhu ruang dan kemudian diukur serapan pada panjang gelombang maksimal yaitu $765 \mathrm{~nm}$ dengan menggunakan spektrofotometer.

$$
\mathrm{C}=\frac{c V}{m}
$$

Dengan:

$\mathrm{C}=$ konsentrasi total fenolik, mg GAE/g

$\mathrm{c}=$ konsentrasi gallic acid, $\mathrm{mg} \mathrm{GAE} / \mathrm{mL}$

$\mathrm{V}=$ volume larutan ekstrak sampel dalam metanol $10 \mathrm{~mL}$

$m=$ massa sampel ekstrak, gram 
Flavonoid (Chang et al., 2002 dan Nugroho et al., 2013)

Metode yang digunakan yaitu dengan menggunakan pereaksi $\mathrm{AICI}_{3}$. Sebanyak $0,5 \mathrm{ml}$ ekstrak buah peredangan konsentrasi 1000 ppm dipipet ke dalam tabung reaksi, ditambahkan 1,5 ml etanol $0,1 \mathrm{ml} \mathrm{AICI} 310 \%, 0,1 \mathrm{ml} \mathrm{CH}_{3} \mathrm{COOH}$ IM dan 2,8 $\mathrm{ml}$ aqudest. Larutan dihomogenkan dan diinkubasi selama 30 menit. Absorbansi larutan di ukur dengan spektrofotometer UV-Vis pada panjang gelombang $415 \mathrm{~nm}$. Pengukuran absorbansi dilakuakan 3 kali ulangan.

Kuersetin digunakan sebagai standar dengan seri konsentrasi 50 ppm, 100 ppm, 150 ppm dan 200 ppm. Kurva kalibrasi kuersetin digunakan untuk menentukan kadar senyawa total flavonoid yang tergandung dalam sampel melalui persamaan regresi dan dinyatakan dalam mg ekuivaken kuersetin ekstrak (mg QE/g ekstrak) dengan rumus perhitungan:

$\begin{array}{cl}\text { Keterangan: } & \\ \text { C } & \text { : Flavonoid (mg QE/g ekstrak) } \\ \text { M } & \text { : Berat ekstrak (g) } \\ \text { C1 } & : \text { Konsentrasi kuersetin (mg/I) } \\ \text { FP } & : \text { Faktor pengenceran } \\ \text { V } & : \text { Volume ekstrak (I) }\end{array}$

$$
\mathrm{C}=C 1 x \frac{V}{M} x \mathrm{FP}
$$

\section{Tanin (Chanwitheesuk et al., 2004)}

Kandungan total tanin ditentukan dengan metode Chanwitheesuk et al., (2004) yang sedikit dimodifikasi. Sebanyak 0,5 gr sampel diekstraksi dengan $10 \mathrm{~mL}$ dietil eter selama 20 jam, kemudian disaring dan residu yang diperoleh dididihkan dengan $100 \mathrm{~mL}$ akuades selama 2 jam, kemudian didinginkan dan disaring. Ekstrak yang diperoleh ditambahkan dengan akuades hingga volume ekstrak $100 \mathrm{~mL}$. Sebanyak $0,1 \mathrm{~mL}$ ekstrak d" itambahkan dengan $0,1 \mathrm{~mL}$ reagen Folin Ciocalteu dan divortex, ditambahkan dengan $2 \mathrm{~mL} \mathrm{Na} \mathrm{CO}_{3}$ dan divortex lagi. Absorbansi dibaca pada $\lambda 760 \mathrm{~nm}$ setelah diinkubasi selama 30 menit pada suhu kamar. Hasil yang diperoleh diplotkan terhadap kurva standar asam tanat yang dipersiapkan dengan cara yang sama. Kandungan total tanin dinyatakan dalam mg asam tanat/kg ekstrak.

\section{Antioksidan (Sharma dan Bhat, 2009)}

Sebanyak $1 \mathrm{ml}$ larutan sampel atau standar dimasukkan kedalam tabung reaksi, lalu penambahan $7 \mathrm{ml}$ methanol (sebagai blanko adalah $8 \mathrm{ml}$ methanol). Suspensi kemudian ditambahkan $2 \mathrm{ml}$ larutan DPPH 0,25 mM (sehingga konsentrasi akhir DPPH dalam larutan menjadi $50 \mu \mathrm{M}$ ) yang kemudian di homogenkan dengan menggunakan vortex. Rangkaian kegiatan reaksi dilakukan pada ruang gelap. Inkubasi dilakukan selama 30 menit pada suhu ruang dan kemudian diukur absorbansinya pada panjang gelombang $517 \mathrm{~nm}$. Kapasitas dinyatakan dalam bentuk persentase penghambatan terhadap radikal DPPH dengan perhitungan:

$$
\text { Kapasitas Antioksidan (\%) }=\frac{(\text { A blanko }- \text { A sampel })}{\text { A blanko }} \times 100 \%
$$

Keterangan:

A blanko = nilai absorbansi blanko,

A sampel = nilai absorbandi larutan sampel 


\section{HASIL DAN PEMBAHASAN}

(Yield)

Perbedaan perlakuan lama ekstaksi berbantu gelombang ultrasonik berpengaruh nyata $(p<0,05)$ terhadap yield ekstrak yang dihasilkan, dan setelah diuji lanjut DMRT pada taraf $5 \%$ menghasilkan beda nyata antar perlakuan. Yield ekstrak yang dihasilkan berkisar antara 13,83\% - 17,86\%. Hasil uji yield ekstrak serbuk kulit melinjo merah dapat dilihat pada Tabel 1.

Tabel 1. Hasil yield ekstrak serbuk kulit melinjo merah

\begin{tabular}{cc}
\hline Perlakuan & Yield $(\%)^{*}$ \\
\hline P1 (10 menit) & $15,20^{\mathrm{c}} \pm 0,04$ \\
P2 (20 menit) & $15,63^{\mathrm{d}} \pm 0,07$ \\
P3 (30 menit) & $17,86^{\mathrm{f}} \pm 0,07$ \\
P4 (40 menit) & $17,55^{\mathrm{e}} \pm 0,06$ \\
P5 (50 menit) & $14,00^{\mathrm{b}} \pm 0,05$ \\
P6 (60 menit) & $13,83^{\mathrm{a}} \pm 0,01$ \\
\hline
\end{tabular}

Keterangan : angka yang diikuti oleh huruf yang berbeda menunjukkan perbedaan yang nyata $(\mathrm{p}<0,05)$

Semakin lama waktu ekstraksi menunjukkan semakin meningkat yield ekstrak yang dihasilkan. Hal ini disebabkan karena kesempatan kulit melinjo untuk kontak dengan pelarut etanol semakin lama sehingga waktu pelarut etanol menembus dinding sel dan menarik senyawa dalam bahan juga semakin lama. Waktu ekstraksi yang semakin lama memungkinkan lebih banyak waktu kontak untuk gelembung kativasi memecahkan sel sampel, sehingga meningkatkan hasil ekstrak komponen bioaktif (Wang et al., 2012). Namun setelah mencapai waktu 30 menit (P3) menunjukkan tidak terjadi peningkatkan yield ekstrak karena telah melewati titik jenuh larutan. Waktu ekstraksi berbantu gelombang ultrasonik yang terlalu lama dapat mendegradasi komponen fenolik, sehingga akan dihasilkan yield yang lebih rendah (Odabas dan Koca, 2016), sebagaimana terjadi pada penelitian Kunarto dan Sani (2018) yang menunjukkan bahwa hasil kulit Durio zibethinus Murr. yang diekstrak menggunakan etanol $70 \%$ menghasilkan yield optimum dengan waktu 20 menit dan terjadi penurunan yield pada waktu 30 menit, serta penelitian Buanasari et al., (2019) menunjukkan bahwa daun Syzygium samarangense yang diekstrak menggunakan etanol 70\% menghasilkan yield tertinggi pada menit ke-30 dan terendah pada menit ke-50. Liu et al., (2018) juga menunjukkan bahwa Phyllanthus urinaria menghasilkan yield optimum pada 30 menit dan menurun setelah waktu 30 menit.

\section{Hasil Uji Fenolik}

Perbedaan perlakuan lama ekstaksi berbantu gelombang ultrasonik berpengaruh nyata $(p<0,05)$ terhadap fenolik ekstrak serbuk kulit melinjo merah yang dihasilkan, dan setelah diuji lanjut DMRT pada taraf $5 \%$ menghasilkan beda nyata antar perlakuan. Aktivitas antioksidan ekstrak yang dihasilkan berkisar antara 1,33 mg GAE/g - 2,74 mg GAE/g. Hasil uji fenolik ekstrak serbuk kulit melinjo merah dapat dilihat pada Tabel 2.

Tabel 2. Hasil fenolik ekstrak serbuk kulit melinjo merah

\begin{tabular}{cc}
\hline Perlakuan & Fenolik (mg GAE/g) \\
\hline P1 (10 menit) & $1,61^{\mathrm{c}} \pm 0,01$ \\
P2 (20 menit) & $1,66^{\mathrm{d}} \pm 0,01$ \\
P3 (30 menit) & $2,74^{\mathrm{f}} \pm 0,01$ \\
P4 (40 menit) & $1,79^{\mathrm{e}} \pm 0,01$ \\
P5 (50 menit) & $1,50^{\mathrm{b}} \pm 0,01$ \\
P6 (60 menit) & $1,33^{\mathrm{a}} \pm 0,01$ \\
\hline
\end{tabular}

Keterangan : angka yang diikuti oleh huruf yang berbeda menunjukkan perbedaan yang nyata $(\mathrm{p}<0,05)$ 
Peningkatan fenolik terjadi seiring dengan peningkatan lama ekstraksi, namun selanjutnya terjadi penurunan fenolik karena pelarut dan zat terlarut telah mencapai titik kesetimbangan (Margaretta et al., 2011), sejalan dengan penelitian pada kulit Durio zibethinus Murr. (Kunarto dan Sani, 2018) dan daun Averrhoa bilimbi L. (Andriani et al., 2019). Waktu ekstraksi yang lebih lama memungkinkan lebih banyak waktu kontak gelembung kativasi untuk memecahkan sel, sehingga total fenolik meningkat (Wang et al., 2012). Namun perpanjangan waktu ekstraksi dapat menyebabkan senyawa senyawa fenolik terpapar cahaya dan oksigen, akibatnya senyawa fenolik dapat teroksidasi sehingga perolehan fenolik menjadi berkurang (Bazykina et al., 2002). Khoddami et al. (2013) juga menyatakan bahwa komponen beberapa fenolik sensitif terhadap panas dan mudah teroksidasi.

\section{Hasil Uji Flavonoid}

Perbedaan perlakuan lama ekstaksi berbantu gelombang ultrasonik berpengaruh nyata $(p<0,05)$ terhadap flavonoid ekstrak serbuk kulit melinjo merah yang dihasilkan, dan setelah diuji lanjut DMRT pada taraf $5 \%$ menghasilkan beda nyata antar perlakuan. Aktivitas antioksidan ekstrak yang dihasilkan berkisar antara 1,25 mg QE/g - 2,30 mg QE/g. Hasil uji flavonoid ekstrak serbuk kulit melinjo merah dapat dilihat pada Tabel 3.

Tabel 3. Hasil flavonoid ekstrak serbuk kulit melinjo merah

\begin{tabular}{cc}
\hline Perlakuan & Flavonoid (mg QE/g) \\
\hline P1 (10 menit) & $1,38^{\mathrm{c}} \pm 0,01$ \\
P2 (20 menit) & $1,42^{\mathrm{d}} \pm 0,02$ \\
P3 (30 menit) & $2,30^{\mathrm{f}} \pm 0,02$ \\
P4 (40 menit) & $1,51^{\mathrm{e}} \pm 0,02$ \\
P5 (50 menit) & $1,32^{\mathrm{b}} \pm 0,01$ \\
P6 (60 menit) & $1,25^{\mathrm{a}} \pm 0,02$ \\
\hline
\end{tabular}

Keterangan : angka yang diikuti oleh huruf yang berbeda menunjukkan perbedaan yang nyata $(\mathrm{p}<0,05)$

Hasil uji flavonoid meningkat sesuai dengan peningkatan lama ekstraksi dan terjadi penurunan flavonoid karena terjadi degradasi termal (Lu et al.,2013). Senyawa flavonoid yang terekstrak semakin meningkat karena semakin lama waktu ekstraksi maka kontak antara bahan dan pelarut akan lebih lama sehingga senyawa flavonoid yang dihasilkan dari ekstrak serbuk kulit melinjo merah akan semakin meningkat walaupun terjadi penurunan setelah memasuki titik jenuh sehingga tidak dapat menghasilkan ekstrak yang lebih banyak lagi. Hasil ini sesuai dengan ekstraksi flavonoid berbantu gelombang ultrasonik pada daun Annona muricata L. yang mengalami degradasi termal dan tidak ada pengaruh nyata setelah kondisi optimum, yaitu 20 menit (Handayani et al., 2016), dan hasil ekstraksi flavonoid pada Dendranthema indicum var. Aromaticum yang juga mengalami degradasi termal dan menurun setelah kondisi optimum pada waktu 30 menit (Zhong et al., 2019).

\section{Hasil Uji Tanin}

Perbedaan perlakuan lama ekstaksi berbantu gelombang ultrasonik berpengaruh nyata $(p<0,05)$ terhadap tanin ekstrak serbuk kulit melinjo merah yang dihasilkan, dan setelah diuji lanjut DMRT pada taraf $5 \%$ menghasilkan beda nyata antar perlakuan. Aktivitas antioksidan ekstrak yang dihasilkan berkisar antara 1,44 mg TAE/g - 2,92 mg TAE/g. Hasil uji tanin ekstrak serbuk kulit melinjo merah dapat dilihat pada Tabel 4. 
Tabel 4. Hasil tanin ekstrak serbuk kulit melinjo merah

\begin{tabular}{cc}
\hline Perlakuan & Tanin mg TAE/g \\
\hline P1 (10 mneit) & $1,73^{\mathrm{c}} \pm 0,01$ \\
P2 (20 menit) & $1,79^{\mathrm{d}} \pm 0,01$ \\
P3 (30 menit) & $2,92^{\mathrm{f}} \pm 0,01$ \\
P4 (40 menit) & $1,91^{\mathrm{e}} \pm 0,01$ \\
P5 (50 menit) & $1,61^{\mathrm{b}} \pm 0,01$ \\
P6 (60 menit) & $1,44^{\mathrm{a}} \pm 0,01$
\end{tabular}

Keterangan : angka yang diikuti oleh huruf yang berbeda menunjukkan perbedaan yang nyata $(p<0,05)$

Semakin lama waktu ekstraksi maka senyawa tanin yang terekstrak juga akan meningkat. Pada waktu yang telah mencapai titik optimal yaitu waktu lebih dari 30 menit akan mengalami penurunan. Hal ini disebabkan karena tanin mengalami kerusakan akibat proses hidrolisis selama proses ekstraksi dan pemanasan yang berlangsung secara terus-menerus (Sukardi et al., 2007). Hasil ini sejalan dengan penelitian pada daun Averrhoa bilimbi L. (Andriani et al., 2019) dengan waktu lebih dari 20 menit tanin akan mengalami penurunan.

\section{Hasil Uji Aktivitas Antioksidan}

Perbedaan perlakuan lama ekstaksi berbantu gelombang ultrasonik berpengaruh nyata $(p<0,05)$ terhadap aktivitas antioksidan ekstrak serbuk kulit melinjo merah yang dihasilkan, dan setelah diuji lanjut DMRT pada taraf 5\% menghasilkan beda nyata antar perlakuan. Aktivitas antioksidan ekstrak yang dihasilkan berkisar antara $65,47 \%-74,33 \%$. Hasil uji aktvitas antioksidan ekstrak serbuk kulit melinjo merah dapat dilihat pada Tabel 5.

Tabel 5. Hasil aktivitas antioksidan ekstrak serbuk kulit melinjo merah

\begin{tabular}{cc}
\hline Perlakuan & Aktivitas Antioksidan (\%) \\
\hline P1 (10 menit) & $69,20^{\mathrm{b}} \pm 0,21$ \\
P2 (20 menit) & $69,69^{\mathrm{c}} \pm 0,32$ \\
P3 (30 menit) & $74,33^{\mathrm{e}} \pm 0,32$ \\
P4 (40 menit) & $73,42^{\mathrm{d}} \pm 0,21$ \\
P5 (50 menit) & $68,78^{\mathrm{b}} \pm 0,21$ \\
P6 (60 menit) & $65,47^{\mathrm{a}} \pm 0,32$ \\
\hline
\end{tabular}

Keterangan : angka yang diikuti oleh huruf yang berbeda menunjukkan perbedaan yang nyata $(\mathrm{p}<0,05)$

Aktivitas antioksidan tertinggi dari ekstrak serbuk kulit melinjo merah berbantu gelombang ultrasonik yaitu pada waktu 30 menit (P3). Hasil ini sesuai dengan kandungan flavonoid (Gambar 3) serta fenolik (Gambar 4) yang dihasilkan. Menurut Patel et al., (2015) keberadaan senyawa fenolik (seperti asam fenolik) berpengaruh terhadap antioksidan. Aktivitas antioksidan meningkat seiring dengan meningkatnya yield, fenolik, flavonoid, dan tanin, namun setelah mencapai titik optimum akan menurun selaras dengan senyawa yang bersifat antioksidan yaitu fenolik, flavonoid, dan tanin. Alfianti (2012) menyatakan bahwa fenolik dan flavonoid yang tinggi mempunyai aktivitas antioksidan yang tinggi. Peningkatan kandungan total fenolik dan total flavonoid pada ekstrak kulit Citrus reticulata juga menunjukkan peningkatan aktivitas antioksidan yang ditandai dengan penurunan nilai $\mathrm{IC}_{50}$ (Chen $e t$ al., 2017) dan aktivitas antioksidan ekstrak daun Averrhoa bilimbi L. (Andriani et al., 2019) meningkat seiring dengan meningkatnya total fenol, total flavonoid, dan total tanin, namun setelah mencapai titik optimum yaitu waktu 20 menit mengalami penurunan. 


\section{Korelasi Antara Fenolik, Flavonoid dan Tanin Terhadap Aktivitas Antioksidan}

Pada penelitian ini, fenolik, flavonoid, dan tanin memiliki kolerasi positif terhadap aktivitas antioksidan berdasarkan penangkapan radikal DPPH. Grafik antara flavonoid, fenolik dan tanin dengan aktivitas antioksidan ekstrak serbuk kulit melinjo merah dapat dilihat pada Gambar 1, 2 dan 3.

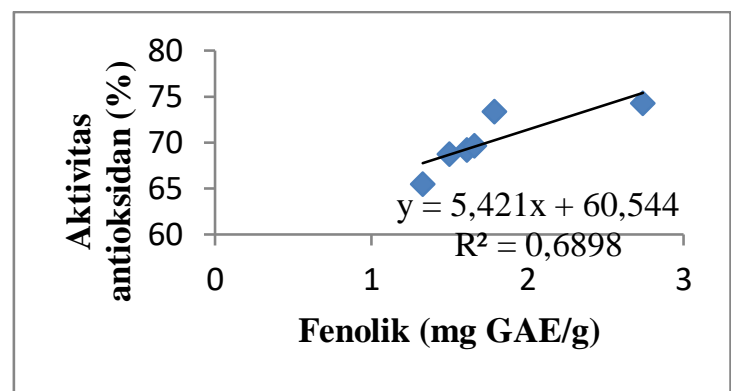

Gambar 1. Grafik hubungan antara fenolik dengan aktivitas antioksidan ekstrak serbuk kulit melinjo merah berbantu gelombang ultrasonik

Koefisien korelasi $\left(\mathrm{R}^{2}\right)$ antara fenolik terhadap aktivitas antioksidan sebesar 0,6898. Menurut Apak et al. (2007) senyawa fenolik berupa flavonoid yaitu flavonol dan flavon dapat berperan sebagai antioksidan. Aktivitas flavonoid sangat bergantung terhadap jumlah dan lokasi gugus $-\mathrm{OH}$ dimana dalam hal ini berperan dalam menetralkan radikal bebas. Kemampuan flavonoid dalam menekan radikal bebas pun berkaitan dengan kemampuannya mendonorkan elektron. Hal inilah yang menyebabkan hubungan antara total fenol dengan aktivitas antioksidan.

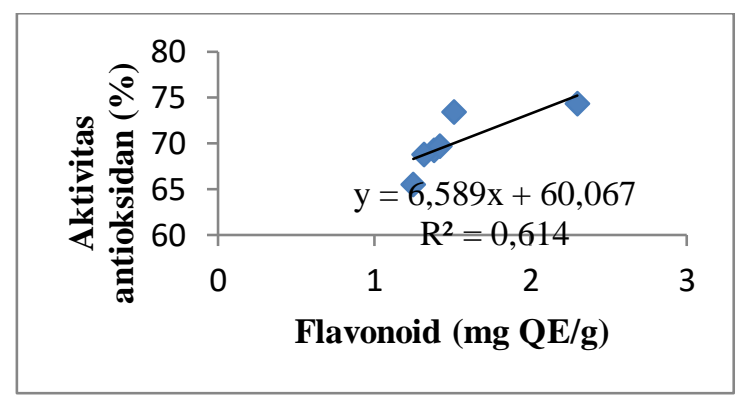

Gambar 2. Grafik hubungan antara flavonoid dengan aktivitas antioksidan ekstrak serbuk kulit melinjo merah berbantu gelombang ultrasonik

Koefisien korelasi $\left(\mathrm{R}^{2}\right)$ antara flavonoid terhadap aktivitas antioksidan sebesar 0,614 . Semakin tinggi nilai fenol dan flavonoid maka semakin tinggi kemampuan antioksidan dalam mendonorkan elektronnya dalam hal menekan perkembangan radikal bebas. Komponen fenolik ataupun flavonoid merupakan senyawa utama dalam peranan antioksidan (Al-Farsi et al., 2007).

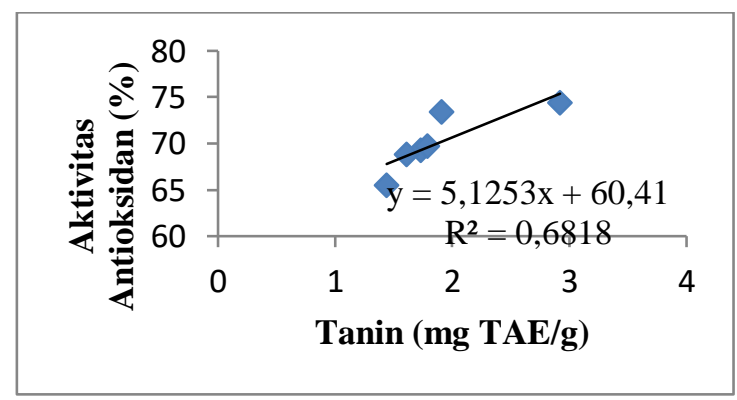

Gambar 3. Grafik hubungan antara tanin dengan aktivitas antioksidan ekstrak serbuk kulit melinjo merah berbantu gelombang ultrasonik 
Koefisien korelasi $\left(\mathrm{R}^{2}\right)$ antara tanin dengan aktivitas antioksidan sebesar 0,6818 . Hasil tersebut menunjukkan bahwa senyawa tanin yang terdapat dalam ekstrak serbuk kulit melinjo merah telah berkontribusi terhadap aktivitas antioksidan. Menurut Rafsanjani dan Putri (2015) menyatakan bahwa semakin banyak kandungan tanin maka semakin besar aktivitas antioksidannya karena tanin tersusun dari senyawa polifenolyang memiliki aktivitas penangkap radikal bebas.

\section{Analisa Keputusan}

Analisa keputusan menggunakan uji de garmo (Sarah-dejesus, 2014) untuk menentukan perlakuan terbaik berdasarkan yield, fenolik, flavonoid, tanin dan aktivitas antioksidan dapat dilihat pada Tabel 6.

Tabel 6. Total nilai penentuan perlakuan terbaik

\begin{tabular}{cl}
\hline Perlakuan & Total nilai \\
\hline P1 & 0,259974159 \\
P2 & 0,312497673 \\
P3 & 1 \\
P4 & 0,541286727 \\
P5 & 0,160287179 \\
P6 & 0 \\
\hline
\end{tabular}

Berdasarkan total nilai diatas dapat dilihat bahwa pada P3 (30 menit) mendapatkan nilai tertinggi dengan jumlah 1 (satu), kemudian disusul P4 (40 menit) dan yang terakhir yaitu P6 (60 menit). Dari data pengamatan tersebut menunjukkan bahwa semakin lama waktu ekstraksi akan menghasilkan yield, fenol, flavonoid, tanin dan aktivitas antioksidan yang tinggi dan setelah melewati batas optimum akan terjadi penurunan (Sekarsari, et al., 2019).

Berdasarkan hasil pengamatan tersebut, maka ditetapkan bahwa P3 (30 menit) merupakan perlakuan terbaik yang memiliki yield, fenolik, flavonoid, tanin dan aktivitas antioksidan tertinggi.

\section{SIMPULAN}

Berdasarkan hasil penelitian pengaruh lama ekstraksi serbuk kulit melinjo merah berbantu gelombang ultrasonik dapat disimpulkan bahwa:

1. Lama ekstraksi kulit melinjo merah berbantu gelombang ultrasonik berpengaruh nyata $(\mathrm{p}<0,05)$ terhadap uji yield, fenolik, flavonoid, tanin dan aktivitas antioksidan.

2. Lama ekstraksi kulit melinjo merah berbantu gelombang ultrasonik terbaik adalah pada waktu 30 menit (P3) dengan hasil yield sebesar 17,86\%, fenolik 2,74 mg GAE/g, flavonoid 2,30 mg QE/g, tanin 2,92 mg TAE/g dan aktivitas antioksidan sebesar 74,33\%.

\section{SARAN}

Perlu dilakukan penelitian lanjutan mengenai senyawa lain yang terdapat dalam ekstrak serbuk kulit melinjo merah berbantu gelombang ultrasonik. 


\section{DAFTAR PUSTAKA}

Al-Juhaimi, F., Adiamo, O.Q., Ghafoor, K., Babiker, E.E. 2016. Optimization of ultrasonic-assisted extraction of phenolic compound from fenugreek (Trigonella foenum-graecum L.) seed. CyTAJournal of Food 14(3):369374. DOI:10.1080/19476337.2015.1110202.

Andriani, M., Permana, I.D.G.M. dan Widarta, I.W.R. 2019. Pengaruh Suhu dan Waktu Ekstraksi Daun Belimbing Wuluh (Averrhoa bilimbi L.) Terhadap Aktivitas Antioksidan dengan Metode UltrasonicAssisted Extraction (UAE). Jurnal Ilmu dan Teknologi Pangan, Vol.8, No.3, 330-340.

Al-Farsi, M., Alasalvar, C., Al-Abid, M., Al-Shoaily, K., Al-Amry, M. \& Al-Rawahy, F. 2007. Composition and Functional Characteristics of Dates, Syrups, and Their by-Products. Food Chemistry, 104:943-947.

Alfianti, U. 2012. Determination Antioxidant Activity on Water Spinach (Ipomea Reptans Poir) Grown Ias Organic Treatement. Report. Chemistry Department, Science and Math Faculty, Riau University (In Bahasa Indonesia).

Apak, R., Guclu, K., Demirata, B., Ozyurek, M., Celik, S., Bekttasoglu, B., Berker, K. \& Ozyurt, D. 2007. Comparative Evaluation of Various Total Antioxidant Capacity Assays Applied to Phenolic Compounds with The CUPRAC Assay. Molecules, 1(2):1496-1547.

Badan Pusat Statistik Provinsi Jawa Tengah. 2019. Statistik Pertanian Hortikultura Provinsi Jawa Tengah 20162018. Jawa Tengah : Badan Pusat Statistik.

Bazykina, N.I., Nikolaevskii, A.N., Fillipenko, T.A. 2002. Optimization of Conditions for The Extraction of Natural Antioxidants from Raw Plant Materials. Pharmaceutical Chemistry Journal, 36(2):46-49.

Buanasari, F.Y., Cholifah, dan Chakim A. 2019. Potensi Metode Ultrasonic-Assisted Extraction (UAE) dalam Mengekstrak Senyawa Aktif dari Bahan Alam. Jurnal Farmasi \& Sains Indonesia, Vol.2, No.1.

Chang, C.C., Yang, M.H., Wem, H.M., and Chern, J.C. 2002. Estimation of Total Flavonoid Content in Propolis by Two Comlpementary Colorimetric Methods. Journal of Food and Drug Analysis, 10 (3): 178-182.

Chanwitheesuk, A., Teerawutgulrag A., Rakariyatham, N. 2004. Screening of Antioxidant Activity and Antioxidant Compounds of Some Edible Plants of Thailand. Food Chemistry. 92, 491-497.

Chen, X.M., Tait, A.R., Kitts, D.D. 2017. Flavonoid Composition of Orange Peel and Its Association with Antioxidant and Anti-Inflammatory Activities. Food Chemistry, 218:15-21. DOI:10.1016/j.foodchem.2016.09.016.

Dewi, A.N. 2018. Toksisitas Akut Ekstrak Etanol Kulit Buah Melinjo (Gnetum gnemon L.) pada Mencit Jantan Galur DIDY [Skripsi]. Bogor: Institut Pertanian Bogor.

Handayani, H., Sriherfyna, F.H., Yunianta. 2016. Ekstraksi Antioksidan Daun Sirsak Metode Ultrasonic Bath. Jurnal Pangan dan Agroindustri Vol. 4 No. 1 p.262-272.

Hou, C., Humphreys, A.M., Thureborn, O., Rydin, C. 2015. New insights into the evolutionary history of Gnetum (Gnetales). Taxon 64(2): 239-253. DOI:10.12705/642.12.

Khoddami, A., Wilkes, M., Roberts, T. 2013. Techniques for Analysis of Plant Phenolic Compounds Molecules 18022328 .

Kunarto, B. 2014. Skrining Fitokimia Ekstrak Etanol Kulit Melinjo (Gnetum gnemon L) Varietas Ketan dan Aktivitas Antioksidannya Setelah Dienkapsulasi. Jurnal Teknologi Pangan dan Hasil Pertanian, 11(1):15-20.

Kunarto, B. dan Pratiwi, E. 2014. Evaluasi Sifat Antioksidatif Mikroenkapsul Ekstrak Kulit Melinjo Merah (Gnetum gnemon L.) yang Dienkapsulasi Menggunakan Gam Arab dan Maltodekstrin. Prosiding Seminar Nasional Nutrisi, Keamanan Pangan dan Produk Halal, Surakarta: 26 April 2014. Hal. 241-247.

Kunarto, B., and Sani, E.Y. 2018. Antioxidant Activity of Extract from Ultrasonic-Assisted Extraction of Durian Peels. Jurnal of Applied Food Technology 5(2) 25-29.

Kunarto, B., Sutardi, Supriyanto, dan Anwar, C. 2019. Optimasi Ekstraksi Berbantu Gelombang Ultrasonik pada Biji Melinjo Kerikil (Gnetum gnemon L., 'Kerikil') Menggunakan Response Surface Methodology. Jurnal Aplikasi Teknologi Pangan, 8(3):104-111.

Liu, Y., She, X., Huang, J., Liu, M., and Zhan, M. 2018. Ultrasonic-exraction of Phenolic Compounds from Phyllanthus urinaria: Optimization Model and Antioxidant Activity. Food Science and Techonoly. DOI:10.1590/1678-457.

Lu, J., Zhou, C., Rong, O., Xu, Y., Zhang, B., Li, Z. 2013. Optimization of Microwave-Assisted Extraction of Flavonoids from Cryptotaenia japonica Hassk Using Response Surface Methodology. Advandce Journal of Food Science and Technology, 5:310-317.

Margaretta, S., Handayani, S.D., Indraswati N dan Hindarso H. 2011. Ekstraksi Senyawa Phenolic Pandanus amaryllifolius Roxb. Sebagai Antioksidan Alami. Vol. 10, No. 1, Hal: 21-30. Fakultas Teknik Kimia Universitas Katolik Widya Mandala, Surabaya.

Nipornram, S., Tochampa, W., Rattanatraiwong, P., Singanusong, R. 2017. Optimization of Low Power Ultrasonic-Assisted Extraction of Phenolic Compounds from Mandarin (Citrus Reticulata Blanco cv. Sainampueng) Peel. Food Chemistry, doi: http://dx.doi.org/10.1016/j.foodchem.2017.08.114.

Nugroho, A. E., Suhardjono, D., Mulyono, S.a, dan Malik, A. 2013. Total Flavanoid and Fenolik Contents and in Vitro Antyhipertention Activity of Indonesia Cashew Leaves anacardiumoccidentale L. Fakultas Farmasi. UGM. Yogyakarta. 
Odabas, H.I. and Koca, I. 2016. Apllication of response surface methodology for optimizing the recovery of phenolic compounds from hazelnut skin using different extraction methods. Industrial Crops and Products 91:114-124. DOI:10.1016/j.indcrop.2016.05.033.

Patel, R., Yogesh, P., Prasant, K., and AnjukUnjadia. 2015. DPPH Free Radical Scavenging Activity of Phenolic of India. International Journal of Current Microbiology and Applied Science, 1(1):773-780.

Rafsanjani, M.K. dan Putri W.D.R. 2015. Karakterisasi Ekstrak Kulit Jeruk Bali Menggunakan Metode Ultrasonic Bath (Kajian Perbedaan Pelarut dan Lama Ekstraksi). Jurnal Pangan dan Agroindustri, Vo.3, No.4:1473-1480.

Sarah-dejesus. 2014. Perhitungan Analisis De Garmo (Perlakuan Terbaik), https://www.slideserve.com/sarahdejesus/perhitungan-analisis-de-garmo-perlakuan-terbaik diakses pada 10 Februari 2020.

Sekarsari, S., Widarta, I.W.R., dan Jambe, A.G.D.N.A. 2019. Pengaruh Suhu dan Waktu Ekstraksi dengan Gelombang Ultrasonik Terhadap Aktivitas Antioksidan Ekstrak Daun Jambu Biji (Psidium guajav L.). Jurnal Ilmu dan Teknologi Pangan, 8(3):267-277.

Sharma, O.P and Bhat, T.K. 2009. Analytical methods DPPH antioxidant assay revisited. Food Chemistry 113: $1202-1205$.

Sukardi, A.R., Mulyatro dan Safera, W. 2007. Optimasi Waktu Ekstraksi Terhadap Kandungan Tanin pada Bubuk Ekstrak Daun Jambu Biji (Psidii folium) dan Biaya Produksinya. Jurnal Teknologi Pertanian, 8(2):8894.

Turrini, F., Boggia, R., Leardi, R., Borriello, M dan Zunin, P. 2018. Optimization of the Ultrasonic-Assisted Extraction of Phenolic Compounds from Oryza sativa L.'Violet Nori' and Determination of the Antioxidant Properties of its Caryopses and Leaves. Molecules 28,844.

Wang, X., Wu, Q., Qu, Y., Chen, G., Yue, W., Liang, Q. 2012. Response surface optimized ultrasonic-assisted extraction of flavonoids from Sparganii rhizoma and evaluation of their in vitro antioxidant activities. Molecules 17(6):6769-6783.

Wazir, D., Ahmad, S., Muse, R., Mahmood, M., Shukor, M.Y. 2011. Antioxidant activities of different parts of Gnetum gnemon L. Journal of Plant Biochemistry and Biotechnology 20(2): 234. DOI:10.1007/s13562-011-00518.

Wen, C., Zhang, J., Zhang, H., Dzah, C.S., Zandile, M., Duan, Y., Ma, H., Luo, X. 2018. Advances in ultrasound assisted extraction of bioactive compounds from cash crops-A review. Ultrasonics Sonochemistry 48:538-549. DOI:10.1016/j.ultsonch. 2018.07.018.

Zhong, L., Liu, Y., Xiong, B., Chen, L., Zhang, Y., and Li, C. 2019. Optimization of Ultrasonic-Assisted Extraction of Total Flavonoids from Dendranthema indicum var. aromaticum by Response Surface Methodology. Journal of Analytical Methods in Chemistry. DOI:10.1155/2019/1648782. 